\title{
Production of Pepper Cultivar Palermo Grafted onto Serrano de Morelos 2, Jalapeño, and Three Commercial Rootstocks
}

\author{
Francisco Doñas-Uclés, Diego Pérez-Madrid, Celia Amate-Llobregat, \\ Enrique M. Rodríguez-García, and Francisco Camacho-Ferre ${ }^{\mathbf{1}}$ \\ Plant Production in Mediterranean Crop Systems Research Group, \\ Advanced Polytechnic School, University of Almeria, Almería 04120, \\ Spain
}

Additional index words. graft, yield, greenhouse, sweet Italian, Capsicum annuum

\begin{abstract}
In the southeast of Spain, specifically in the province of Almería, pepper production represents $1.70 \%$ of the total pepper (Capsicum annuum L.) production in the world, which in turn represents $31.8 \%$ of the European production. In the last 10 years, production has remained stable between 7,240 and 10,997 ha. Due to the economic importance of this crop in the region, more improvements of the production techniques have been adopted. The reduced number of commercial rootstocks of peppers, which really improve yield in this crop, causes a continuous search for new genotypes. In this experiment, five pepper rootstocks were evaluated in an experimental design of randomized blocks with six treatments and three repetitions. The rootstocks used were: 'Serrano de Morelos 2' (SCM-334), 'Jalapeño', 'Oscos', ‘AR 9604040', and 'Tresor'. The cultivar grafted onto them was 'Palermo' also used as a control test. SCM-334 cultivar used as rootstock has a similar behavior in the production parameters measured as the commercial pepper rootstocks which were used. 'Jalapeño' and 'SCM-334' demonstrated different behavior in plant vigour compared with the others treatments. There is no interrelationship between production and plant vigour provided by the rootstock.
\end{abstract}

In 2012, 31,171,570 $\mathrm{t}$ of peppers (Capsicum annuиm L.) were produced in the world, in an area of 1.9 million ha (FAOSTAT, 2012). Spain is the sixth largest pepper producing country in the world, with $1.023,700 \mathrm{t}$, and Almería in the southeast of Spain is the main production region of sweet pepper in the world (López-Marín et al., 2013) with an area of 8406 ha and a production of 540,590 t (Junta de Andalucía, 2013). Regarding the areas of sweet pepper grown under greenhouse, the regions of Murcia and Alicante follow Almería, and in these regions 1900 ha are produced annually (López-Marín et al., 2009).

The high concentration of pepper production areas under monocropping conditions has been irremediably associated with the use of chemical products during the course of many years, which has caused a decrease of the biodiversity of agricultural ecosystems with harmful consequences such as the increase in the number of diseases and pathogens in crop soils (Crinó et al., 2007; Zavaleta-Mejía, 2000). Meloidogyne incognita is considered as the main root pathogen associated with pepper crops, and the main

Received for publication 21 Apr. 2015. Accepted for publication 29 May 2015.

Project RTA 2010-00038-C03-02 financed by INIA-Spain.

${ }^{1}$ To whom reprint requests should be addressed; e-mailfcamacho@ual.es. root fungal disease is Phytophthora capsici (Gisbert et al., 2010). Furthermore, other pathogens such as Phytophthora nicotianae var. parasitica ( $P$. parasitica), are also considered as a problem, although, in the case of peppers grown under greenhouse, it has not been much studied (Pérez Vargas, 2011). A high incidence of these pathogens, among others, has been described in the pepper crops of southeast Spain (Guerrero et al., 2005, 2013; Núñez-Zofio et al., 2013).

Methyl Bromide (MeBr), was considered as the best known soil fumigant so far, and it was traditionally used as a control method for P. capsici and M. incognita (Bello et al., 1997 quoted by Bello et al., 2001; López-Marín et al., 2009, 2013; Lacasa et al., 1999); however, $\mathrm{MeBr}$ was declared as an ozonedepleting substance at the fourth Meeting of the Montreal Protocol in Copenhagen in Nov. 1992 (Noling and Becker, 1994; RodríguezKábana, 1997). The main problem of $\mathrm{MeBr}$ is that when it is injected directly into the soil the mass flow has a higher trend to rising movement than to descending movement, therefore, its use was banned in Spain as well as in the whole of the European Union in 2005 (Bello et al., 2001), and its worldwide withdrawal is foreseen in 2015 (Gullino et al., 2003). According to the mentioned Montreal Protocol, there are few soil fumigant options available due to the environmental impact of most of these chemicals. In Spain, since 1997, in addition to many conferences and seminars (Bello et al., 2000; Lacasa et al., 2004), several projects coordinated by the government ministries concerned with agriculture, education, and environment have been carried out with the purpose of evaluating different alternatives, chemical and nonchemical, to the use of $\mathrm{MeBr}$, which permit the continuation of the crop systems established in the different areas, including the crop of sweet peppers in the southeast of Spain (Bolívar, 1997 quoted by Bello et al., 2001). Among the alternatives that are being researched, we can find biofumigation (which is carried out with residues of fresh vegetable material and hen and sheep manure), which has obtained good results in Spain (Bello et al., 2001; Guerrero et al., 2005; Lacasa et al., 2000), biosolarisation and grafting onto resistant rootstocks (Lacasa et al., 2004; Piedra Buena et al., 2006), which have proved effective when both techniques have been combined in the control of $P$. capsici (Guerrero et al., 2002). Grafting onto resistant rootstocks offers one of the best ways to avoid soil-borne diseases (Vitale et al., 2014; Sakata et al., 2007). Currently, the use of grafting is being extended by a significant portion of growers for the control of such diseases (Tsaballa et al., 2013). In fact, the main reason to use it is because it contributes to decrease damages caused, not only in pepper, but also in other crops, by soil pathogens such as Fusarium, Verticillium, or Nematodes (King et al., 2008; Lee, 2003; Passam, 2003), Monosporascus, and Melon necrotic spot virus (MNSV) (Boughalleb et al., 2007; Edelstein et al., 1999; Miguel, 2005; Sigüenza et al., 2005), and even protects against MNSV, which cannot be controlled with $\mathrm{MeBr}$ applications (Cohen et al., 2007). In fact, since the use of $\mathrm{MeBr}$ was banned, grafting has gradually become the most common and effective technique for the control of soilborne diseases, such as Phytophthora sp. and Meloidogyne sp. (López-Marín et al., 2009, 2013). According to Morra (1997), resistance to pathogens is associated with a vigorous root system.

The initial purpose of the grafting method was to avoid or reduce the incidence of soilborne diseases and nowadays there are rootstocks compatible with sweet peppers, which provide tolerance to diseases such as $P$. capsici, Sweet pepper mosaic virus (BePMV), and Tomato mosaic virus (ToMV) (Oda, 2008 quoted by Louws et al., 2010; Palada and $\mathrm{Wu}, 2008$ ), although later researches have provided some other advantages (Lee, 1994) from patterns that may contribute to improving crops under flood conditions, high salt concentrations, or soil toxicity, to even increasing the efficiency of nutrient use as nitrogen (He et al., 2009; Liao and Lin, 1996; Rouphael et al., 2008; Ruiz and Romero, 1999; Yetisir et al., 2006), showing a better behavior with low levels of available potassium (Schwarz, et al., 2013), or improving efficiency under some low temperature conditions (Palada and $\mathrm{Wu}$, 2008). However, the use of grafting in pepper 
plants is not as widespread as in the rest of horticultural species (Lee et al., 2010), as with the case of cucurbits, the main family of grafted plants worldwide (Cohen et al., 2007).

In spite of the fact that the use of the adequate rootstock through grafting can be an alternative strategy to avoid or reduce yield losses caused by the reasons mentioned above, in addition it provides other advantages in other species and families, mainly cucurbits. The lack of research related with the use of grafting in peppers has caused a lack of information about grafting behavior, with respect to compatibility of rootstock variety, development of grafted plants, tolerance to biotic and abiotic stresses, and influence of pattern on fruit quality in sweet peppers (Colla et al., 2008; López-Marín et al., 2013). However, recent works show that the use of some combinations of rootstock variety may provide advantages with respect to higher yield and higher pepper fruit quality (Doñas-Uclés et al., 2014; Tsaballa et al., 2013).

Overall, the reason that could have given rise to the increased use of the grafting technique in vegetables is the increased density of pathogen's inoculum in the soil, due to the intensification of production practices, and the disappearance of traditional varieties adapted to the crop conditions. These varieties were also used to meet the demands of local and specific markets (Sakata et al., 2007). The goal of this research was to evaluate the behavior of pepper commercial rootstocks and two traditional pepper cultivars. The rootstocks were assessed for yield and standard quality parameters.

\section{Materials and Methods}

The experiment was carried out during the Spring season of 2013, coinciding with the professional farmers' production calendar of "Italian sweet peppers" in the region. The facilities used were those of the foundation's "Experimental Plot at the University of Almería, Anecoop," in the municipality of Almería, Spain $\left(36^{\circ} 51^{\prime} 78^{\prime \prime}\right.$ North latitude and $2^{\circ} 17^{\prime} 08^{\prime \prime}$ West longitude). The pepper crop was grown after a melon crop under a plastic greenhouse without heating.

Grafting was made in expanded polystyrene trays $(698 \mathrm{~mm} \times 475 \mathrm{~mm} \times 75 \mathrm{~mm})$ with 150 cells ( $35 \mathrm{~mm} \times 30 \mathrm{~mm}$ in size), and they were covered with plastic as a phytosanitary control measure. Due to the electrical conductivity (EC) of water used for irrigation, which is close to $2 \mathrm{dS} \cdot \mathrm{m}^{-1}$, the most appropriate substrate with which the trays were filled was a mixture of $70 \%$ blonde peat + $20 \%$ black peat $+10 \%$ of perlite from 2 to $3 \mathrm{~mm}$, covered with a thin layer of vermiculite of granulometry from 0 to $3 \mathrm{~mm}$.

The seedbed of the plant in the nursery was formed by a multitunnel greenhouse covered by three-layer polyethylene of 3 years duration. Nutrition was supplied through a nutritional solution, at the beginning with EC of $1 \mathrm{dS} \cdot \mathrm{m}^{-1}$ increasing gradually until the grafted plant was fully developed in the nursery at $2.5 \mathrm{dS} \cdot \mathrm{m}^{-1}$. The $\mathrm{pH}$ of the nutritional solution was adjusted to 5.8 .

The grafting method used was "splice" (Lee et al., 2010). This type of grafting permits working with smaller plants, and trays with lower volume cells can be used. Furthermore, it is faster executing and therefore more economically efficient, but the main advantage is that it permits the union of all the vascular bundles of rootstock variety, which at the beginning makes for a more vigorous plant. However, this method requires stable climate conditions during the healing stage with temperatures between 23 and $26{ }^{\circ} \mathrm{C}$ and a relative humidity during the first days of postgrafting of $93 \%$ to $97 \%$. The sowing date was the same for all the cultivars as well as the rootstocks. Grafting was carried out when seedlings that were going to be used as cultivars had four true leaves and the plant diameter used as rootstock had the same stem size as the cultivar. Grafting was conducted by making a bevel cut, at about a $45^{\circ}$ angle below cotyledons, in the rootstock as well as in the cultivars and using a silicone plastic clip to fasten it. Cutting below cotyledons prevents the rootstock sprouting again, although it increases the possibility of rooting cultivar grafted onto the rootstock because grafting has to be made at the lower part. Grafting was carried out $25 \mathrm{~d}$ after sowing. Plants were in the nursery until $58 \mathrm{~d}$ after sowing under controlled environmental conditions.

The crop was carried out on soil covered by sand described by (Camacho and Fernández, 2000 ), where a sand layer covered a $60 \mathrm{~cm}$ horizon of a clay loam soil, with $1 \%$ of organic matter, $\mathrm{pH}$ of 7.1 and $\mathrm{EC}(\mathrm{CE})$ in the saturated extract of $1.51 \mathrm{dS} \cdot \mathrm{m}^{-1}$. The analysis of the saturated extract showed values of $2 \mathrm{mmol} \cdot \mathrm{L}^{-1}$ of $\mathrm{Ca}^{2+}, 1.32 \mathrm{mmol} \cdot \mathrm{L}^{-1}$ of $\mathrm{Mg}^{2+}$, $9.13 \mathrm{mmol} \cdot \mathrm{L}^{-1}$ of $\mathrm{Na}^{+}, 11.13 \mathrm{mmol} \cdot \mathrm{L}^{-1}$ of $\mathrm{Cl}^{-1}$, and $0.34 \mathrm{mmol} \cdot \mathrm{L}^{-1}$ of $\mathrm{HCO}_{3}{ }^{-1}$. Fertigation was carried out using a drip irrigation system, with self compensating drippers of
$3 \mathrm{~L} \cdot \mathrm{ha}^{-1}$ discharge, where the following nutritional solution was applied: $12 \mathrm{mmol} \cdot \mathrm{L}^{-1}$ of $\mathrm{NO}_{3}^{-}, 1.5 \mathrm{mmol} \cdot \mathrm{L}^{-1}$ of $\mathrm{H}_{2} \mathrm{PO}_{4}^{-}, 1.5$ $\mathrm{mmol} \cdot \mathrm{L}^{-1}$ of $\mathrm{SO}_{4}{ }^{2-}, 6 \mathrm{mmol} \cdot \mathrm{L}^{-1}$ of $\mathrm{K}^{+}$, $5 \mathrm{mmol} \cdot \mathrm{L}^{-1}$ of $\mathrm{Ca}^{2+}$, and $2 \mathrm{mmol} \cdot \mathrm{L}^{-1}$ of $\mathrm{Mg}^{2+}$. The greenhouse soil was analyzed before the beginning of the experiment by the pathology laboratory of the University of Almería, and no pathogen was found. Visual symptoms of Phytophthora spp. and Meloidogyne spp. were not observed in the plants at the end of the experiment.

An experiment of randomized blocks was designed with six treatments and three replications.

The treatment used as a control test was nongrafted Palermo cultivar, which is commercialised by Rijk Zwaan. The rest of treatments were 'Palermo' grafted onto open pollination cultivars (nonhybrid), SCM-334 and Jalapeño, used in this case as rootstocks. All the treatments were planted at a planting density of 2.3 plants $/ \mathrm{m}^{2}$, the same as the densities used by the region's farmers of "Sweet Italian" peppers, and were staked at two sprouts, obtaining a total density of 4.6 sprouts $/ \mathrm{m}^{2}$.

The commercial description of the vegetal material, which was used in this experiment is as follows (Marín-Rodríguez, 2015):

'Palermo': (Rijk Zwaan Co.) An Italian pepper type with resistances and high yield under low temperature conditions. It is a very hardy plant, with good fruit setting under low temperatures. Fruits have a conical shape and medium green color, and they maintain a constant length throughout the production cycle. They have a very glossy and fairly smooth skin. This is a versatile pepper that can be harvested green and also red. It has an excellent taste, color, and firmness. It is recommended for planting in autumn and early spring in a greenhouse, and in the spring in the open fields or under mesh. It has a high resistance to Tobacco mosaic virus (TMV): $0-2$.

Table 1. Description of treatments and elemental plots.

\begin{tabular}{llcccc}
\hline Treatments & Rootstock & No. plants & Area $\left(\mathrm{m}^{2}\right)$ & $\begin{array}{c}\text { Planting density } \\
\left(\text { plants } / \mathrm{m}^{2}\right)\end{array}$ & $\begin{array}{c}\text { Stem density } \\
\left(\mathrm{stems} / \mathrm{m}^{2}\right)\end{array}$ \\
\hline T0 & Palermo & 134 & 58.26 & 2.3 & 4.6 \\
T0 & Palermo & 134 & 58.26 & 2.3 & 4.6 \\
T0 & Palermo & 134 & 58.26 & 2.3 & 4.6 \\
T1 & Oscos & 134 & 58.26 & 2.3 & 4.6 \\
T1 & Oscos & 134 & 58.26 & 2.3 & 4.6 \\
T1 & Oscos & 134 & 58.26 & 2.3 & 4.6 \\
T2 & AR40 & 134 & 58.26 & 2.3 & 4.6 \\
T2 & AR40 & 134 & 58.26 & 2.3 & 4.6 \\
T2 & AR40 & 134 & 58.26 & 2.3 & 4.6 \\
T3 & Tresor & 134 & 58.26 & 2.3 & 4.6 \\
T3 & Tresor & 134 & 58.26 & 2.3 & 4.6 \\
T3 & Tresor & 134 & 58.26 & 2.3 & 4.6 \\
T4 & SCM-334 & 134 & 58.26 & 2.3 & 4.6 \\
T4 & SCM-334 & 134 & 58.26 & 2.3 & 4.6 \\
T4 & SCM-334 & 134 & 58.26 & 2.3 & 4.6 \\
T5 & Jalapeño & 134 & 58.26 & 2.3 & \\
T5 & Jalapeño & 134 & 58.26 & 2.3 & \\
T5 & Jalapeño & 134 & 58.26 & 2.3 & \\
\hline
\end{tabular}


'Oscos': (Ramiro Arnedo Co.) This is a rootstock with good affinity to the different varieties of pepper. It has good root development, which provides great vigour

Table 2. Task calendar.

\begin{tabular}{lcc}
\hline Sowing date & \multicolumn{2}{c}{ 2 Nov. 2012 } \\
\cline { 2 - 3 } Grafting date & \multicolumn{2}{c}{ 7 Dec. 2012 } \\
\cline { 2 - 3 } Planting date & \multicolumn{2}{c}{ 9 Jan. 2013 } \\
\cline { 2 - 3 } Measurements & Yield & Plant ht \\
\hline & - & 15 Apr. 2013 \\
& 14 May 2013 & - \\
& 10 June 2013 & 10 June 2013 \\
& 19 June 2013 & - \\
& 5 July 2013 & - \\
& 19 July 2013 & - \\
& 1 Aug. 2013 & 1 Aug. 2013 \\
& 23 Aug. 2013 & - \\
& 24 Sept. 2013 & - \\
End of crop & 27 Sept. 2013 & 26 Sept. 2013 \\
\hline
\end{tabular}

to the crop and favors the good formation and structure of the plant, thus maintaining fruit quality. It has tolerance to problems of root asphyxia incited by flooding and to the most common soil diseases, such as Phytophthora and Nematodes. It is resistant to TMV: 0 .

'Tresor F1': (Nunhems Co.) This is a rootstock of high compatibility and affinity with the different types and varieties of pepper. It has a good root system, which enhances the plant development. Root system with a good behavior in soils infected with the most common diseases (Intermediate resistance): Phytophthora (P. capsici), Nematodes (M. arenaria, $M$. incognita, Meloidogyne javanica). Furthermore, it has intermediate resistance to Potato virus $\mathrm{Y}: 0.1$ and high resistance to TMV:0/ BePMV/TMV/ ToMV (L1).
Table 3. Accumulated yields of commercial fruits and total fruit per meter square and per plant, obtained in the different treatments applied to different experiments.

\begin{tabular}{|c|c|c|c|c|}
\hline \multirow[b]{2}{*}{ Treatments } & \multicolumn{2}{|c|}{ Commercial yield } & \multicolumn{2}{|c|}{ Total yield } \\
\hline & $\begin{array}{l}\text { Accumulated } \\
\text { yield }\left(\mathrm{kg} \cdot \mathrm{m}^{-2}\right)\end{array}$ & $\begin{array}{c}\text { Accumulated } \\
\text { yield }(\mathrm{kg} / \text { plant })\end{array}$ & $\begin{array}{l}\text { Accumulated } \\
\text { yield }\left(\mathrm{kg} \cdot \mathrm{m}^{-2}\right)\end{array}$ & $\begin{array}{l}\text { Accumulated } \\
\text { yield ( } \mathrm{kg} / \text { plant) }\end{array}$ \\
\hline$\overline{\mathrm{T} 0}$ & $7.30 \mathrm{ab}$ & $3.17 \mathrm{ab}$ & $7.80 \mathrm{ab}$ & $3.39 \mathrm{ab}$ \\
\hline $\mathrm{T} 1$ & $8.31 \mathrm{a}$ & $3.61 \mathrm{a}$ & $8.94 \mathrm{a}$ & $3.89 \mathrm{a}$ \\
\hline $\mathrm{T} 2$ & $7.65 \mathrm{ab}$ & $3.33 \mathrm{ab}$ & $8.21 \mathrm{ab}$ & $3.57 \mathrm{ab}$ \\
\hline $\mathrm{T} 3$ & $7.19 \mathrm{ab}$ & $3.12 \mathrm{ab}$ & $7.70 \mathrm{ab}$ & $3.37 \mathrm{ab}$ \\
\hline $\mathrm{T} 4$ & $6.67 \mathrm{ab}$ & $2.90 \mathrm{ab}$ & $7.27 \mathrm{ab}$ & $3.16 \mathrm{ab}$ \\
\hline $\mathrm{T} 5$ & $6.20 \mathrm{~b}$ & $2.69 \mathrm{~b}$ & $6.53 \mathrm{~b}$ & $2.84 \mathrm{~b}$ \\
\hline$P$ value & 0.035 & 0.035 & 0.033 & 0,033 \\
\hline
\end{tabular}

Different letters show significant differences to $95 \%$ with $P<0.05$. LSD test.

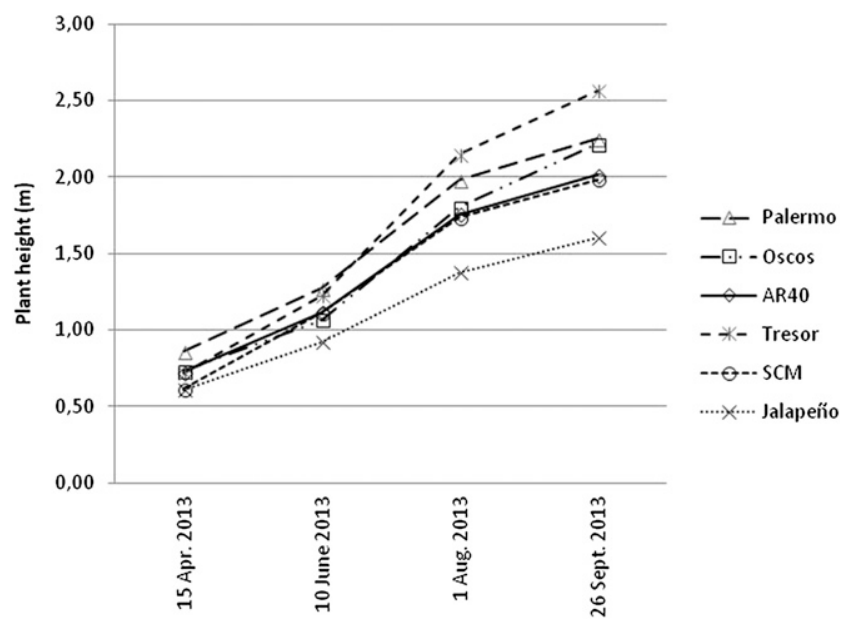

Fig. 1. Plant height throughout the cycle.

Table 4. Plant height measured in the different treatments throughout the crop cycle.

\begin{tabular}{lcccc}
\hline & \multicolumn{4}{c}{ Plant ht measured throughout the cycle $(\mathrm{m})$} \\
\cline { 2 - 5 } Treatments & Measurement 1 & Measurement 2 & Measurement 3 & Measurement 4 \\
\hline T0 & $0.86 \mathrm{a}$ & $1.27 \mathrm{a}$ & $1.98 \mathrm{ab}$ & $2.25 \mathrm{ab}$ \\
T1 & $0.73 \mathrm{~b}$ & $1.06 \mathrm{ab}$ & $1.80 \mathrm{ab}$ & $2.21 \mathrm{ab}$ \\
T2 & $0.73 \mathrm{~b}$ & $1.12 \mathrm{ab}$ & $1.76 \mathrm{ab}$ & $2.01 \mathrm{abc}$ \\
T3 & $0.72 \mathrm{bc}$ & $1.22 \mathrm{a}$ & $2.15 \mathrm{a}$ & $2.56 \mathrm{a}$ \\
T4 & $0.62 \mathrm{bc}$ & $1.11 \mathrm{ab}$ & $1.73 \mathrm{ab}$ & $1.98 \mathrm{bc}$ \\
T5 & $0.61 \mathrm{c}$ & $0.92 \mathrm{~b}$ & $1.38 \mathrm{~b}$ & $1.60 \mathrm{c}$ \\
$P$ value & 0.003 & 0.048 & 0.022 & 0.049 \\
\hline
\end{tabular}

Different letters mean significant differences to $95 \%$ with $P<0.05$. LSD test.
'AR-96040 F1' (AR40): (Ramiro Arnedo Co.) It provides great vigour to the crop. It provides a fast development at the beginning of the crop. Good affinity with the different cultivars onto it can be used. Good root development under flooding conditions. This rootstock is less vigorous than 'Oscos' and keeps quality parameters in relation with resistances, and it also increases fruit setting during the whole cycle.

'SCM-334' and 'Jalapeño': There is not a commercial description using cultivars SCM-334 and Jalapeño as rootstocks, because they are open pollinated cultivars. Both cultivars are Chile types and belong to Capsicum annum var. annum species and are grown frequently in Mexico. Furthermore, the resistance of 'SCM-334' to $P$. capsici has been shown (Alcántara and Bosland, 1994; Bosland and Lindsey, 1991), although with certain controversy (Gil Ortega et al., 1991; Reifschneider et al., 1992).

Treatments, number of plants used, area of the elemental plot, planting density, and sprouts are given in Table 1.

In each of the harvests, the parameters measured were: total accumulated yield per square meter, total accumulated yield per plant, for which a scale was used (Rue de Baldenheim 12, BP 10221, F-67820, Wittisheim, France), with EKS scales and a capacity for $40 \mathrm{~kg}( \pm 10 \mathrm{~g})$. Individual fruit weight for which a scale was used (Rue de Baldenheim 12, BP 10221, F-67820), with capacity for $5 \mathrm{~kg}( \pm 1 \mathrm{~g})$ and, finally, data referring to plant height were taken throughout the cycle (Table 2).

Differences between treatments were determined using the multifactor variance analysis, where significant differences $(P<0.05)$ among the different treatments were showed, the Duncan's multiple range test and Fisher's least significant differences (LSD) were determined. The statistical software program STATGRAPHICS Centurión XVI was used for tests and calculations.

\section{Results}

Accumulated yield per square meter. The treatment with higher commercial production was T1 ('Palermo' onto 'Oscos') with 8.31 $\mathrm{kg} \cdot \mathrm{m}^{-2}$, followed by T2 ('Palermo' onto 'AR40') and T0 (nongrafted 'Palermo'). Significant differences were not found between treatments, except for $\mathrm{T} 1$ and $\mathrm{T} 5$ ('Palermo' onto 'Jalapeño') in which 6.20 $\mathrm{kg} \cdot \mathrm{m}^{-2}$ were harvested. The parameter total accumulated yield per square meter had a similar behavior (Table 3 ).

Accumulated yield per plant. The data analysis showed the same behavior with respect to accumulated yield per plant, the treatment with the highest commercial accumulated yield per plant was T1, with $3.61 \mathrm{~kg} /$ plant, followed by T2 with $3.32 \mathrm{~kg} / \mathrm{plant}$. T0 obtained $3.17 \mathrm{~kg} /$ plant. Again, T5 obtained 
the lowest accumulated yield per plant (2.69 $\mathrm{kg} /$ plant). There were only significant differences between the treatments $\mathrm{T} 1$ and $\mathrm{T} 5$ (Table 3).

Plant height. Height at specific dates for the different treatments varied throughout the cycle (Fig. 1). In the first measurement of plant height, the treatment that showed more height was $\mathrm{T} 0$, but at the end of the crop, the higher treatment was T3 ('Palermo' onto 'Tresor'), slightly exceeding $2.5 \mathrm{~m}$ in height. $\mathrm{T} 3$ only showed significant differences in this parameter compared with the treatments $\mathrm{T} 4$ ('Palermo' onto 'SCM 334') and T5 ('Palermo' onto 'Jalapeño'), this last treatment showing the lowest height at the end of the cycle with $1.60 \mathrm{~m}$ (Table 4 ).

\section{Discussion}

Significant differences were not found among rootstock treatments in regards to yield. This result is consistent with DoñasUclés et al. (2014) who used Palermo as cultivar. This fact also happened to Estañ et al. (2005) and Savvas et al. (2011) in the experiments carried out with tomatoes. The results stated before showed that grafting effect with respect to commercial yield depends on the rootstock used. It is shown that treatments in which a commercial rootstock is used obtained higher yields compared with treatments in which 'SCM-334' and 'Jalapeño' were used, although in the case of the former there were no significant differences compared with the treatments in which commercial rootstocks were used. Nongrafted 'Palermo' did not show significant differences compared with the other commercial rootstock with respect to the yield parameters and vigour measured in this experiment.

A priori, according to Miguel (1997) and Santos and Goto (2004) one of the main problems that arises when grafting peppers is the decrease of plant vigour, although in this experiment this has not always been the case, because final vigour depended on the rootstock used. These results could be consistent with those obtained by Cohen et al. (2007) and Passam (2003), who stated that grafting can lead to higher plant vigour as a result of a higher efficiency in the obtaining of water and nutrients, increasing earliness and total yield.

The data analysis contrasts with that obtained by García Rodríguez et al. (2010), whose work included commercial rootstocks 'Tresor' and 'Atlante', as well as the noncommercial cultivar SCM-334, which significantly reduced plant vigour. On the other hand, the watermelon works carried out by Huitrón et al. (2009) concluded that grafting increases vigour and crop yield.

\section{Conclusions}

Specific combinations of rootstock variety may give better yields, whether per area as well as per plant.

SCM-334 cultivar could be used as pepper rootstocks under the crop conditions described previously, because they do not affect significantly yield parameters compared with the commercial pepper rootstocks actually used.

Results do not show an interrelationship between yield and plant height that induces the combination rootstock variety.

Future research opportunities, using SCM-334 cultivar as rootstock under other pepper typologies, have been generated after this experiment.

\section{Literature Cited}

Alcántara, T.P. and P.W. Bosland. 1994. An inexpensive disease screening technique for foliar blight of chile pepper seedlings. HortScience 29:1182-1183.

Bello, A., J.A. López, R. Sanz, M. Escuer, and J. Herrero. 2000. Biofumigation and organic amendments. In: Regional Workshop on Methyl Bromide Alternatives for North Africa and Southern European Countries. UNEP. p. 113-141.

Bello, A., J.A. López-Pérez, L. Díaz-Viruliche, and T. Tello. 2001. Alternatives to Methil bromide for soil fumigation in Spain, Vol. 166, p. 31-42. In: R. Labrada and L. Formasari (eds.). Global report on validated alternatives to the use of methyl bromide soil fumigation. Plant production and protection paper. FAO, Rome.

Bosland, P.W. and D.L. Lindsey. 1991. A seedling screen for Phytophthora root rot of pepper, Capsicum annuum. Plant Dis. 75:1048-1050.

Boughalleb, N., N. Tarchoun, A. El Mbarki, and M. Mahjoub. 2007. Resistance evaluation of nine cucurbit rootstocks and grafted watermelon (Citrullus lanatus L.) varieties against fusarium wilt and fusarium crown and root rot. J. Plant Sci. 2:102-107.

Camacho, F. and E.J. Fernández. 2000. El cultivo de sandía apirena injertada, bajo invernadero, en el litoral mediterráneo español. Caja Rural de Almería, Almería, Spain.

Cohen, R., Y. Burger, C. Horeb, A. Koren, and M. Edelstein. 2007. Introducing grafting cucurbits to modern agriculture. The Israeli experience. Plant Dis. 91:916-923.

Colla, G., Y. Rouphael, M. Cardarelli, O. Temperini, E. Rea, A. Salerno, and F. Pierandrei. 2008. Influence of grafting on yield and fruit quality of pepper (Capsicum annuum L.) grown under greenhouse conditions. Acta Hort. 782:359-363.

Crinó, P., C. Lo Bianco, Y. Rouphael, G. Colla, F. Saccardo, and A. Paratore. 2007. Evaluation of rootstock resistance to Fusarium wilt and gummy stem blight and effect on yield and quality of a grafted "Inodorus" melon. HortScience 42:521-525.

Doñas-Uclés, F., M. Jiménez-Luna, J. GóngoraCorral, D. Pérez-Madrid, D. Verde-Fernández, and F. Camacho-Ferre. 2014. Influence of three rootstocks on yield and commercial quality of "Italian Sweet" pepper. Ciênc. Agrotec. 38:538-545.

Edelstein, M., R. Cohen, Y. Burger, and S. Shriver. 1999. Integrated management of sudden wilt in melons, caused by Monosporascus cannonballus, using grafted and reduced rates of methyl bromide. Plant Dis. 83:1142-1145.

Estañ, M.T., M.M. Martinez-Rodriguez, F. PerezAlfocea, T.J. Flowers, and M.C. Bolarin. 2005. Grafting raises the salt tolerance of tomato through limiting the transport of sodium and chloride to the shoot. J. Expt. Bot. 56:703-712.

FAOSTAT. 2012. Production/crops. 7 Oct. 2014 $<$ http://faostat3.fao.org/faostat-gateway/go/to/ download/Q/*/S $>$.
García-Rodríguez, M.R., E. Chiquito-Almanza, D. Loeza-Lara, E. Godoy-Hernández, E. VillordoPineda, J.L. Pons-Hernández, M. GonzálezChavira, and J.L. Anaya-López. 2010. Production of ancho chili graft on Criollo de Morelos 334 for the control of Phytophthora capsici. Agrociencia 44:701-709.

Gil Ortega, R., C.P. Espanol, and J.C. Zueco. 1991. Genetics of resistance to Phytophthora capsici in the pepper line 'SCM-334'. Plant Breed 107:50-55.

Gisbert, C., P. Sánchez-Torres, M.D. Raigón, and F. Nuez. 2010. Phytophthora capsici resistance evaluation in pepper hybrids: Agronomic performance and fruit quality of pepper grafted plants. J. Food Agr. Environ. 8:116-121.

Guerrero, M.M., A. Lacasa, C. Ros, P. Guirao, M.A. Martínez, N. Barceló, A. Bello, P. Fernández, and A. González. 2002. La reiteración de la biofumigación con solarización y los efectos en la desinfección de suelos de invernaderos de pimiento. XI Congreso de la SEF, Almería, 14 18 de octubre. Resúmenes. p. 245.

Guerrero, M.M., C. Ros, M.A. Martínez, M.C. Martínez, N. Barceló, and A. Lacasa. 2005. Biofumigación con solarización. Un método estable de desinfección de suelos de invernadero. Acta Portuguesa de Hort. 7(3):111-115.

Guerrero-Díaz, M.M., C. Lacasa, A. Hernández, V. Martínez, and A. Lacasa. 2013. Evaluation of repeated biodisinfestation using Brassica carinata pellets to control Meloidogyne incognita in protected pepper crops. Span. J. Agr. Res. 11(2):485-493.

Gullino, M.L., A. Camponogara, G. Gasparrini, V. Rizzo, C. Clini, and A. Garibaldi. 2003. Replacing methyl bromide for soil desinfestation. Plant Dis. 87:1012-1021.

He, Y., Z. Zhu, J. Yang, X. Ni, and B. Zhu. 2009. Grafting increases the salt tolerance of tomato by improvement of photosynthesis and enhancement of antioxidant enzymes activity. Environ. Expt. Bot. 66:270-278.

Huitron-Ramírez, M.V., M. Ricardez-Salinas, and F. Camacho-Ferre. 2009. Influence of grafted watermelon plant density on yield and quality in soil infested with melon necrotic spot virus. HortScience 44:1838-1841.

Junta de Andalucía. 2013. Memoria Resumen de la Consejería de Agricultura, Pesca y Desarrollo Rural de Junta de Andalucía, p. 243. In: Junta de Andalucía (eds.).

King, S.R., A.R. Davies, W. Liu, and A. Levi. 2008. Grafting for disease resistance. HortScience 43:1673-1676.

Lacasa, A., P. Guirao, M.M. Guerrero, C. Ros, J.A. López-Pérez, A. Bello, and P. Bielza. 1999. Alternatives to methyl bromide for sweet pepper cultivation in plastic greenhouses in south east. 3rd International Workshop Alternatives to Methyl Bromide for the Southern European Countries. 7-10 Dec. Crete, Greece. p. 133135.

Lacasa, A., P. Guirao, M.M. Guerrero, C. Ros, J.A. López-Pérez, A. Bello, and P. Bielza. 2000. Proc. Int. Workshop on Alternatives to MB for the Southern European Countries. Agric. Minist. of Greece-DGXII. p. 133-135.

Lacasa, A., M.A. Guerrero, and M. Oncina. 2004. Desinfección de suelos en invernaderos de pimiento. II Jornadas sobre alternativas viables al bromuro de metilo en invernadero. CAAM. Murcia, Jornadas 16:355.

Lee, J.M. 1994. Cultivation of grafted vegetables. I. Current status, grafting methods, and benefits. HortScience: A publication of the American Society for Horticultural Science. 
Lee, J.M. 2003. Advances in vegetable grafting. Chron. Hort. 43(2): 13-19.

Lee, J.M., C. Kubota, S.J. Tsao, Z. Bie, P. HoyosEchevarria, L. Morra, and M. Oda. 2010. Current status of vegetable grafting: Diffusion, grafting techniques, automation. Sci. Hort. 127:93-105.

Liao, C.T. and C.H. Lin. 1996. Photosynthetic responses of grafted bitter melon seedlings to flood stress. Environ. Expt. Bot. 36:167-172.

López-Marín, J., A. Gálvez, A. González, and J.A. Fernández. 2009. Agronomic behavior of grafted sweet pepper grown in a greenhouse in mediterranean area. Acta Hort. 807:655660.

López-Marín, J., A. Gonzalez, F. Pérez-Alfocea, C. Egea-Gilabert, and J.A. Fernández. 2013. Grafting is an efficient alternative to shading screens to alleviate thermal stress in greenhousegrown sweet pepper. Sci. Hort. 149:39-46.

Louws, F.J., L. Cary, C.L. Rivard, and C. Kubota. 2010. Grafting fruiting vegetables to manage soilborne pathogens, foliar pathogens, arthropods and weeds. Sci. Hort. 127:127-146.

Marín-Rodríguez, J. 2015. Portagrano. Vademécum de variedades hortícolas. In: José Marín (ed.). El Ejido. Edición XIV. p. 290-295.

Miguel, G.A. 1997. Injerto de Hortalizas. Generalitat Valencia. In: Federico Doménech S.A. (eds.). Valencia, Spain. p. 88.

Miguel, A. 2005. Use of grafted cucurbits in mediterranean region as an alternative to methyl bromide. Proc. Fifth International Conference on Alternatives to Methyl Bromide, European Commission, Lisbon, Portugal. p. 75-80.

Morra, L. 1997. L'innesto erbaceo coltura per coltura. Colt Prot. 5:17-22.

Noling, J.W. and J.O. Becker. 1994. The challenge of research and extension to define and implement alternatives to methyl bromide. J. Nematol. 26(4 Suppl.):573-586.
Núñez-Zofio, M., S. Larregla, C. Garbisu, M.M. Guerrero, C.M. Lacasa, and A. Lacasa. 2013. Application of sugar beet vinasse followed by solarization reduces the incidence of Meloidogyne incognita in pepper crops while improving soil quality. Phytoparasitica 41:181-191.

Palada, M.C. and D.L. Wu. 2008. Evaluation of chili rootstocks for grafted sweet pepper production during the hot-wet and hot-dry seasons in Taiwan. Acta Hort. 767:167-174.

Passam, H. 2003. Use of grafting makes comeback. Fruit Veg. Tech. 3(4):7-9.

Pérez-Vargas, M. 2011. Epidemiología y control de Phytophthora parasítica en cultivos de tomate y pimiento bajo abrigo en el Sureste Peninsular de España. Ual, PhD Diss. p. 211.

Piedra-Buena, A., M.A. García, C. Díez, P. Ros, A. Fernández, A. Lacasa, and A. Bello. 2006. Use of pepper crop residues for the control of root-knot nematodes. Bioresour. Technol. 98:2846-2851.

Reifschneider, F.J.B., L.S. Boiteux, P.T. Della Vecchia, J.M. Poulos, and N. Kuroda. 1992. Inheritance of adult-plant resistance to Phytophthora capsici in pepper. Euphytica 62:45-49.

Rodríguez-Kábana, A. 1997. Alternatives to methyl bromide (MB) soil fumigation, p. 1734. In: A. Bello, J.A. Gonzalez, M. Arias, and R. Rodríguez-Kabana (eds.). Alternatives to methyl bromide for the southern European countries. CSIC, Madrid, Spain.

Rouphael, Y., M. Cardarelli, E. Rea, and G. Colla. 2008. Grafting of cucumber as a means to minimize copper toxicity. Environ. Expt. Bot. 63:49-58.

Ruiz, J.M. and L. Romero. 1999. Nitrogen efficiency and metabolism in grafted melon plants. Sci. Hort. 81:113-123.

Sakata, Y., T. Ohara, and M. Sugiyama. 2007. The history and present state of the grafting of cucurbitaceous vegetables in Japan. Acta Hort. 731:159-170.
Santos, H.A. and R. Goto. 2004. Enxertia em plantas de pimentao no controle da murcha de fitóftora em ambiente protegido. Hort. Bras. 22:45-49.

Savvas, D., A. Savva, G. Ntatsi1, A. Ropokis, I. Karapanos, A. Krumbein, and C. Olympios. 2011. Effects of three commercial rootstocks on mineral nutrition, fruit yield, and quality of salinized tomato. J. Plant Nutr. Soil Sci. 174:154-162.

Sigüenza, C., M. Schoshow, T. Turini, and A. Ploeg. 2005. Use of Cucumis metuliferus as a rootstock for melon to manage Meloidogyne incognita. J. Nematol. 37(3):276-280.

Schwarz, D., G.B. Öztekin, Y. Tüzel, B. Brückner, and A. Krumbein. 2013. Rootstocks can enhance tomato growth and quality characteristics at low potassium supply. Sci. Hort. 149:70-79.

Tsaballa, A., C. Athanasiadis, K. Pasentsis, I. Ganopoulos, I. Nianiou-Obedat, and A. Tsaftaris. 2013. Molecular studies of inheritable grafting induced changes in pepper (Capsicum annuиm) fruit shape. Sci. Hort. 149:2-8.

Vitale, A., M. Rocco, S. Arena, F. Giuffrida, C. Cassaniti, A. Scaloni, T. Lomaglio, V. Guarnaccia, G. Polizzi, M. Marra, and C. Leonardi. 2014. Tomato susceptibility to Fusarium crown and root rot: Effect of grafting combination and proteomic analysis of tolerance expression in the rootstock. Plant Physiol. Biochem. 83:207-216.

Yetisir, H., M.E. Çaliskan, S. Soylu, and M. Sakar. 2006. Some physiological and growth responses of watermelon [Citrullus lanatus (Thunb.) Matsum. and Nakai] grafted onto Lagenaria siceraria to flooding. Environ. Expt. Bot. 58:1-8.

Zavaleta-Mejía, E. 2000. Alternativas de manejo de las enfermedades de las plantas. Terra Latinoamericana 17:201-207. 